\title{
Invazivní druhy ryb a jejich vnímání vybranými skupinami studentů a sportovních rybářů
}

Prof. RNDr. Lubomír Hanel, CSc. a Mgr. David Goldstein

Envigogika 8 (5) - Recenzované články/ Reviewed Papers

Publikováno/Published 31. 12. 2013

DOI: $\underline{10.14712 / 18023061.417}$

\begin{abstract}
Abstrakt
Invazivní druhy jsou jedním z klíčových faktorů člověkem způsobovaných změn ekosystémů v globálním měřítku. $V$ tomto příspěvku jsou pomocí dotazníků vyhodnoceny názory dvou skupin respondentů (středoškolských studentů/studentek a sportovních rybářů) na přitomnost, význam a nebezpečí nepůvodních invazivních rybích druhů přítomných na území České republiky. Výsledky ukazují u obou skupin respondentů v podstatě dobrou orientaci a znalosti v problematice nepůvodních druhů ryb a jejich nebezpečí pro nativní ichtyofaunu.
\end{abstract}

\section{Klíčová slova:}

invazivní druhy ryb; dotazníkové šetření; názory studentů a sportovních rybářů; Česká republika

Non-native invasive fishes and their perception by selected groups of students and anglers

\section{Abstract}

One of the key drivers of the human-caused global environmental change are invasive alien species. The opinions of the two respondent groups (secondary school students and adult anglers) are analyzed by questionnaires with respect to the presence, relevance and the hazards of non-native (alien) invasive fishes presented in the Czech Republic. The results in both groups of respondents show relatively good orientation and knowledge in the field of problems of non-native fish species and their threat to native ichtyofauna.

\section{Key words:}

non-native invasive fishes; questionnaire; opinions of students and anglers; Czech Republic 


\section{Úvod}

Otázky týkající se nepůvodních druhů ryb a jejich vlivu na původní ichtyofaunu jsou řešeny celosvětově. Stejně jako jakékoli transporty organizmů mimo jejich přirozený areál se tento problém velmi výrazně dotýká environmentální výchovy, zejména v tom smyslu, že ve společnosti na toto téma panují často radikálně odlišné názory (Plesník, 2011). Postoje k př́tomnosti cizorodých organismů v ekosystémech Ize mimo jakoukoli pochybnost ovlivnit školním vzděláváním. Předložená práce se věnuje výsledkům takového vzdělávání; konkrétně jde o porovnání názorů studentů a studentek (dále jen "studenti") s postoji skupiny respondentů, kteří rybářství provozují jako volnočasovou aktivitu.

Vlastní mechanismus výskytu nepůvodních druhů ryb byl studován mnohými autory nejen v zahraničí (např. Fergusson, 1990; Allendorf, 1991; Cows, 1997; García-Berthou, 2007) ale i u nás (např. Lusk, Lusková a Halačka, 1998; Lusk a kol., 2000; Lusk a Lusková, 2005; Mlíkovský a Stýblo, 2006; Lusk, Lusková a Hanel, 2008; Hanel a Lusk, 2012). Aktuální podrobné shrnutí této problematiky uvádějí Lusk, Lusková a Hanel $(2008,2011)$, kteří charakterizují nejnebezpečnější invazivní druhy ryb pro naše území. Ze 33 zde uvedených druhů ryb introdukovaných na území České republiky byly čtyři vyhodnoceny jako reálně invazivní: střevlička východní (Pseudorasbora parva), karas stř́břitý (Carassius gibelio), sumeček americký (Ameiurus nebulosus) a nově k nám proniknuvší hlaváč černoústý (Neogobius melanostomus). Introdukce nepůvodních druhů se ukázaly $v$ mnoha regionech v řadě př́padů jako velmi škodlivé pro původní biodiverzitu, a proto byly vypracovány "Zásady a pravidla postupu při introdukci a reintrodukci vodních živočichů do České republiky". Podle uvedeného dokumentu by komise pro introdukci vodních živočichů při Ministerstvu zemědělství ČR měla posuzovat navrhované introdukce nebo reintrodukce nepůvodních druhů ryb (Holčík, 1990). Za hlavní problémy introdukcí ryb Ize považovat prostorovou a potravní konkurenci s původními druhy, možnost zavlečení nových parazitů či nemocí a prípadné křižení nově introdukovaných druhů $s$ původními. Problematika invazivních druhů má evidentně mezinárodní rozměr, takže např. v rámci Evropy jsou navrhovány určité společné strategie v boji proti těmto vetřelcům (Genovesi a Shine, 2003). Na základě současných poznatků je všeobecně zdůrazňována potřeba komplexní ochrany naší původní ichtyofauny (Hanel a Lusk, 2012).

Problematice praktických dopadů introdukcí a naturalizací nepůvodních ryb na nativní ichtyofaunu je věnována zvýšená pozornost, a to i z legislativního hlediska (Pokorná, 2011). Dosud ale nebylo studováno vnímání této otázky u studentů, a to ani u nás, ani v zahraničí. To je obsahem tohoto príspěvku, kde jsou názory studentů navíc srovnány s postoji aktivních sportovních rybářu. Tento příspěvek navazuje na diplomovou práci Davida Goldsteina (2012).

\section{Materiál a metodika}

\section{Oblast výzkumu a charakteristika respondentů}

Sběr dat probíhal v letech 2011-2012. Za oblast výzkumu názorů mezi studenty bylo zvoleno město Praha. Respondenti pocházeli z následujících škol: Gymnázium Jižní Město, Gymnázium Sázavská, Gymnázium J. G. Jarkovského, Sportovní gymnázium Přípotoční a Gymnázium Omská. Vybraní respondenti (celkem 100) byli studenti třetích ročníků. Výběr studentů nebyl nijak specielně korigován, pro dotazníkové šetření byli vždy využiti všichni studenti z jednotlivých tříd třetího ročníku. Společným rysem respondentů z řad studentů byla skutečnost, že všichni již absolvovali ekologickou část výuky biologie. Dále se dotazníkové akce zúčastnilo dvacet studentů třetího ročníku Obchodní akademie 
Vinohradská Praha 2 a Podnikatelské akademie Prahy 11, kde se vyučuje odborný předmět zbožíznalství, součástí kterého je mimo jiné i biologie a ekologie. I tito studenti již př́slušné informace $v$ rámci výuky před vyplňováním dotazníků získali. Obě tyto skupiny studentů proto mohly být sloučeny do jednoho společného vzorku (tzn. celkem bylo pracováno se 120 respondenty). Většinu dotazovaných studentů tvořily dívky (60 \%).

Srovnávanou skupinou respondentů (100 osob) pak byli aktivní sportovní rybári. Těm byly osobně postupně předávány dotazníky na vyplnění přímo $v$ terénu ve vybraných sportovních rybářských revírech (Sázava 2, Konopištský rybník, Údolní nádrž Orlík, Údolní nádrž Mušov, Otava v oblasti města Strakonice), prípadně v prostorách rybářských prodejen, které jsou specializované na lov dravých ryb (Rybářské potřeby ZERP, Rybářské potřeby Tomi -Korda). Při předání dotazníku sportovním rybářům byl proveden cílený výběr respondentů a do dotazníkového šetření byli zařazeni jen ti aktivní rybáři, kteří se specializují na lov dravých ryb (např. štiky, candáta, sumce). Při jejich lovu se totiž často používají i dva výše zmíněné druhy invazivních ryb (karas stříbřitý a střevlička východní), jejichž živé jedince Ize běžně získat $v$ rybářských prodejnách. Ve vzorku respondentů/respondentek sportovních rybářů převažovali jednoznačně muži ( $95 \%)$.

Uvedené dvě skupiny respondentů byly vybrány z toho důvodu, aby mohly být srovnány názory studentů a jejich znalosti o problematice invazivních druhů získané povětšinou jen ze školní výuky, a na druhé straně názory aktivních sportovních rybářù, kteří čerpají především z vlastních praktických zkušeností.

Předané dotazníky u obou sledovaných skupin respondentů byly rádně vyplněny a mohly být tudíž všechny zahrnuty do analýzy.

\section{Struktura dotazníků a zpracování dat}

Pro sběr dat a jejich následného vyhodnocení byla zvolena metoda dotazníkového šetření, otázky se zaměřovaly na znalosti a vztah respondentů k invazivním druhům ryb. Pro potřeby získání výchozích dat byl sestaven jednoduchý dotazník, který obsahoval osm uzavřených otázek (respondenti odpovídali jednoznačně "ano" či "ne", př́padně vybírali jednu ze tří nabídnutých odpovědí). Pouze u otázky č. 9 byli vyzváni, aby svou odpověd'ještě zdůvodnili. Při samotné tvorbě dotazníků a jejich vyhodnocování bylo postupováno dle publikací Chrásky (2010) a Pelikána (2011). Dotazníky byly anonymní, respondent pouze $v$ úvodu uvedl, zda je muž či žena.

Položené otázky v dotazníku byly následující:

1) Máte nějakou vlastní zkušenost s chovem ryb (akvárium, zahradní jezírko)?

2) Máte zkušenosti se sportovním rybolovem?

3) Myslíte si, že je vhodné, aby se v našich vodách vyskytovalo více rybích druhů než nyní?

4) Jak byste charakterizovali invazivní druh? Zaškrtněte správnou odpověd'.

a) Nepůvodní druh na daném území, který se nekontrolovatelně šiří a negativně působí na původní obyvatele ekosystému.

b) Druh, který je rozšířen jen na určitém omezeném území a nikde jinde se nevyskytuje 
c) Druh nepůvodní, který ale nijak neohrožuje ekosystém, v němž se nově vyskytuje.

5) Jaký důsledek mohou mít invazivní druhy pro naše vodní ekosystémy? Zaškrtněte zvolenou odpověd'.

a) Konkurují původním obyvatelům ekosystému, které mohou svým počínáním různým způsobem omezovat až vytlačovat.

b) Znemožňují rozmnožování všech původních druhů.

c) Často mohou být prospěšné původním obyvatelům daného ekosystému.

6) Které z uvedených rybích druhů jsou na našem území považovány za invazivní?

Možnosti: candát, karas stř́břitý, střevlička východní, sumec, štika.

7) Je vhodné do našich vod vysazovat nebo zde rozšiřovat invazivní druhy ryb?

8) Která z uvedených našich nepůvodních ryb nejvíce narušuje vodní ekosystémy v ČR?

a) amur bílý, b) sumeček americký, c) karas stříbřitý

9) Je eliminace (omezování početnosti) invazních rybích druhů na našem území žádoucí? Uved'te proč.

Tento dotazník byl použit u obou srovnávaných skupin respondentů. Dotazníkovou akcí bylo celkem získáno 220 vyplněných dotazníků. Shromážděná data byla přenesena nejprve z papírové do elektronické podoby $v$ programu MS Office Excel 2002, ve kterém se následně provedly i výpočty popisné statistiky. U tř́ nejzásadnějších otázek (č. 3, č. 7, č. 9) bylo provedeno statistické srovnání rozdílnosti odpovědí u zkoumaných vzorků respondentů pomocí X kvadrátu.

\section{Výsledky a diskuse}

$\checkmark$ tabulce č. 1 jsou přehledně uvedeny výsledky odpovědí studentů a sportovních rybářư na otázky z dotazníku. Studenti středních škol byli vybráni jako vhodná skupina pro výzkum zejména z toho důvodu, že již absolvovali rozšírenou výuku biologie zahrnující i ekologii a environmentální studie a měli by tudíž mít alespoň teoretické základní informace o invazivních druzích. Na gymnáziích navíc existují mnohde různé biologické a environmentální semináře či kroužky, kde studenti mohou získávat hlubší informace týkající se aktuálních ekologických problematik včetně invazivních druhů organismů. Za další důležitý aspekt Ize považovat možnost absolvování terénních prací a exkurzí, které poskytují studentům rozšiřrený pohled na ekologické problémy každodenní praxe. Druhá cílová skupina, sportovní rybáři, byla zvolena proto, že jde o skupinu, která se našimi rybami aktivně zabývá prostřednictvím sportovního rybolovu a může se tak s invazními druhy ryb setkávat. Informace o této problematice tedy mají sportovní rybáři především ze své praxe. 
Tabulka č. 1 Porovnání výsledků dotazníkového šetření na vzorcích středoškolských studentů $(n=120)$ a aktivních sportovních rybářů $(n=100)$.

\begin{tabular}{|c|c|c|c|}
\hline & Odpovědi & $\begin{array}{c}\text { Studenti a studentky } \\
\text { středních škol }\end{array}$ & Sportovní rybáři \\
\hline \multirow{2}{*}{ Otázka č. 1} & ANO & $48 \%$ & $85 \%$ \\
\hline & NE & $52 \%$ & $15 \%$ \\
\hline \multirow{2}{*}{ Otázka č. 2} & ANO & $20 \%$ & $100 \%$ \\
\hline & NE & $80 \%$ & $0 \%$ \\
\hline \multirow{2}{*}{ Otázka č. 3} & ANO & $62 \%$ & $22 \%$ \\
\hline & NE & $38 \%$ & $78 \%$ \\
\hline \multirow{3}{*}{ Otázka č. 4} & a) & $88 \%$ & $96 \%$ \\
\hline & b) & $0 \%$ & $1 \%$ \\
\hline & c) & $12 \%$ & $3 \%$ \\
\hline \multirow{3}{*}{ Otázka č. 5} & a) & $78 \%$ & $96 \%$ \\
\hline & b) & $14 \%$ & $1 \%$ \\
\hline & c) & $8 \%$ & $3 \%$ \\
\hline \multirow{5}{*}{ Otázka č. 6* } & candát obecný & $10 \%$ & $0 \%$ \\
\hline & karas stř́ibřitý & $37 \%$ & karas stř́břitý $18 \%$ \\
\hline & $\begin{array}{l}\text { střevlička } \\
\text { východní }\end{array}$ & $37 \%$ & $\begin{array}{c}\text { střevlička východní } \\
8 \% \text {, střevlička } \\
\text { východní + karas } \\
\text { stř́břitý } 74 \% \\
\end{array}$ \\
\hline & sumec velký & $6 \%$ & $0 \%$ \\
\hline & štika obecná & $10 \%$ & $0 \%$ \\
\hline \multirow{2}{*}{ Otázka č. 7} & ANO & $34 \%$ & $3 \%$ \\
\hline & NE & $66 \%$ & $97 \%$ \\
\hline \multirow{3}{*}{ Otázka č. 8} & a) & $30 \%$ & $2 \%$ \\
\hline & b) & $28 \%$ & $11 \%$ \\
\hline & c) & $42 \%$ & $87 \%$ \\
\hline \multirow{2}{*}{ Otázka č. 9} & ANO & $100 \%$ & $95 \%$ \\
\hline & NE & $0 \%$ & $5 \%$ \\
\hline
\end{tabular}

*Pozn. Vzhledem ke kombinovaným odpovědím sportovních rybářů jsou u této otázky evidované typy odpovědí konkrétně rozepsány

$Z$ tabulky č. 1 jsou patrny určité rozdíly mezi oběma skupinami respondentů. Pouze menší část oslovených studentů (20\%) mělo praktickou zkušenost s chovem ryb a jejich lovem, takže jejich odpovědi vycházejí především ze znalostí získaných ve školní výuce. Výsledky této podskupiny (rybářu a akvaristů z řad studentů) jsou očekávané, tzn. odpovědi byly $v$ průměru správnější než u zbývající podskupiny studentů, kteří tento kontakt neměli (vzhledem k velmi rozdílné četnosti jednotlivých odpovědí u těchto podskupin nebyly odpovědi vyhodnoceny statisticky). Lze předpokládat, že studenti věnující se chovu ryb, či 
jejich lovu (byt́ zatím jen krátkodobě) získávali potřebné informace také z odborné literatury, ve které jsou mnohdy zmiňovány invazivní druhy ryb a jiných živočichů a jejich vliv na naše původní druhy. Skutečnost menšího kontaktu s praktickým rybařením u většiny respondentů z řad studentů může souviset s odpovědí na otázku č. 3, kde si $62 \%$ studentů přeje, aby naše vody byly druhově pestřejší $s$ ohledem na rybí faunu. $U$ sportovních rybářů naopak jasně převažovala u téže otázky záporná odpověd' (78 \%), což Ize vysvětlit především vlastními zkušenostmi $z$ praktického rybolovu, které byly pravděpodobně doplněny $i$ informacemi prezentovanými především $v$ rybářských časopisech. Při statistickém vyhodnocení kladných a záporných odpovědí obou skupin respondentů u této otázky byla vypočtená hodnota testového kritéria výrazně větší než kritická hodnota ( $\mathrm{x}$ kvadrát, $\mathrm{p}<$ 0,001 ). Nicméně studentům i rybářum je již dobře znám termín „invazivní druh" ( $88 \%$ resp. $96 \%$ správných odpovědí u otázky č. 4). Z odpovědí na otázku č. 5 je patrné, že obě skupiny respondentů poměrně dobře vědí, jaké dopady na vodní ekosystémy mohou invazivní druhy ryb mít. U otázky č. 6 , týkající se výběru invazivních ryb z pěti uvedených druhů, byly odpovědi většinou správné, u sportovních rybářů ale byla správnost výrazně vyšší (žádný rybář totiž neuvedl mezi invazivními rybami na našem území sumce, štiku ani candáta, zatímco u studentů se tyto ryby celkově objevily ve $26 \%$ odpovědí).

U otázky č. 7 převažoval u obou sledovaných skupin respondentů názor, že není vhodné do našich vod vysazovat nebo zde rozšiřovat invazivní druhy ryb; rozdíl v odpovědích nebyl zjištěn jako statisticky významný ( $x$ kvadrát, $p>0,05$ ).

Odpovědi na otázku č. 9 byly do značné míry shodné, nebot' pouhých $5 \%$ respondentů z řad sportovních rybářủ by invazivní druhy neeliminovalo a všichni dotazovaní studenti uváděli eliminaci invazních druhů ryb jako žádoucí. Nicméně zjištěný rozdíl v odpovědích byl zjištěn jako statisticky významný ( $x$ kvadrát, $p<0,02$ ). Odpovědi ve všech prípadech byly zdůvodněny konstatováním v tom smyslu: "aby nedocházelo $k$ narušování biodiverzity ichtyofauny České republiky". Celkem 95\% oslovených rybářù uvedlo, že eliminace invazivních druhů ryb je rovněž žádoucí s tím, že prakticky všichni upozornili na úbytek některých původních druhů ryb právě v souvislosti s vlivem druhů invazivních. Podíváme-li se na výsledky dotazníkového šetření jako na celek vypovídající o současném stavu vědomostí studentů středních škol, musíme konstatovat, že se v problematice invazivních druhů ryb poměrně dobře orientují a uvědomují si jejich dopad na vodní ekosystémy České republiky (souvisí to zjevně se zařazením této problematiky do výuky, ale i prezentacemi tohoto tématu $v$ odborné i populárně vědecké literatuře či veřejných sdělovacích prostředcích včetně internetu).

Odpovědi sportovních rybářů získané dotazníkovým šetřením byly ve většině otázek věcně správné. Lze předpokládat, že důvodem toho je zejména jejich letitá praxe a sledování rybích společenstev při samotném sportovním rybolovu, kdy mohou dobře registrovat změny ve skladbě rybí fauny a různými způsoby na tuto skutečnost reagovat. Stojí ale za to připomenout, že právě prostřednictvím některých sportovních rybářů, kteří se specializují na lov dravých ryb, dochází v některých oblastech k nežádoucímu rozšiřování invazivních rybích druhů. Jako živé nástrahy totiž rybáři používají zejména běžně dostupné druhy ryb, které jsou oblíbené pro svou odolnost (střevlička východní, karas stříbřitý). Stává se někdy, že zbytek nespotřebovaných živých nástražních rybek vypustí do rybářských revírů, kde sami loví, a tím vlastně přispívají $k$ jejich šíření. Svým způsobem překvapivé odpovědi rybářů přineslo vyhodnocení otázky č. 3. Plných $22 \%$ sportovních rybářů se domnívá, že by bylo zajímavé, aby naše vody byly druhově rozmanitější (existují totiž také príklady neinvazivních nepůvodních rybích druhů). Tento názor Ize odvodit od jejich lačnosti po kapitálních úlovcích exotických druhů ryb, která je u mnoha rybářu podporována atraktivními, bohatě fotograficky dokumentovanými rybářskými magazíny a $v$ poslední době i filmy zaměřenými na lov trofejních jedinců. $Z$ hlediska úspěšnosti lovu trofejních ryb stojí za zmínku, že u 
některých druhů (kapr, candát, sumec, štika) se nacházejí v našich tekoucích i stojatých vodách kapitální kusy, které se umístúují na špičkách mezinárodních žebříčků evidujících největší úlovky jednotlivých druhů ryb (Hanel, 1989). Zejména jejich lovem si tak mohou rybáríi plnit svá přání zdolávat kapitální jedince. Navíc dnes již není velký problém vycestovat do světa k domovským vodám rybářsky atraktivních exotických ryb, takže se stále více rozšiřuje tzv. rybářská turistika. Je to rozhodně správnější př́stup, než se snažit dovážet do našich vod nové exotické druhy se všemi negativními následky s tím spojenými.

Pokud bychom analyzovali stejným způsobem tutéž problematiku na výrazně početnějším vzorku studentů (za předpokladu obdobného výběru) i z jiných škol v rámci ČR, Ize očekávat podobné výsledky. Př́padné určité rozdíly $v$ odpovědích by mohly být ovlivněny u studentů zejména př́stupem učitelů a jejich větším či menším důrazem na téma invazivních druhů, názorností výkladu či uváděním konkrétních příkladů př́mo z oblasti rybářství. $V$ př́padě analýz založených na větším vzorku sportovních rybářu zaměřených na lov dravých ryb autoři očekávají obdobné výsledky. Je možné, že údaje prezentované $v$ tomto článku budou inspirovat $\mathrm{k}$ dalšímu rozsáhlejšímu průzkumu této problematiky, což může přispět i k ověření těchto hypotéz.

\section{Závěr}

$\mathrm{Na}$ základě vlastních výsledků uvedených $\mathrm{v}$ tomto článku Ize konstatovat, že středoškolští studenti, kteří se zúčastnili dotazníkového šetření, již měli poměrně dobré znalosti o problematice invazivních druhů ryb, což Ize vysvětlit tím, že se toto téma stává nedílnou součástí výuky biologie a ekologie na školách, ale je i častěji prezentováno $\checkmark$ různých odborných i populárně naučných publikacích i přírodovědných filmech. Také respondenti $z$ řad sportovních rybářu díky svým praktickým zkušenostem v podstatě dobře znali okolnosti spojené s invazivními druhy ryb a chápali nebezpečí jejich šíření.

Nicméně považujeme i nadále za potřebné při výuce na školách průběžně informovat o nových aspektech spojených $s$ touto tématikou, stejně tak zařazovat tyto informace i na školeních sportovních rybářů a $v$ rybářských kroužcích $v$ rámci výchovy mladé rybářské generace.

\section{Literatura}

- Allendorf, F. W. (1991). Ecological and genetic effects of fish introduction synthesis and recommendation.Canadian Journal of Fisheries and Aquatic Science, 12(S1), 178-181. Retrieved from http://www.nrcresearchpress.com/doi/abs/10.1139/f91-318 http://dx.doi.org/10.1139/f91-318

- Cowx, I. G. (1997). Introduction of fish species into European fresh waters: economic successes or ecological disasters?. Bulletin Français de la Pêche et de la Pisciculture, 344-345.

- Fergusson, M. M. (1990). The genetic impact of introduced fishes on native species. Canadian Journal of Zoology,68(5), 1053-1057. Retrieved from http://www.nrcresearchpress.com/doi/abs/10.1139/z90-153 http://dx.doi.org/10.1139/z90-153

- García-Berthou, E., \& Supplement, D. (2007). The characteristics of invasive fishes: what has been learned so far.Journal of Fish Biology, 71, 33-35. Retrieved 
from http://doi.wiley.com/10.1111/j.1095-8649.2007.01668.x http://dx.doi.org/10.1111/j.1095-8649.2007.01668.x

- Genovesi, P., \& Shine, C. (2003). European strategy and invasive alien species. Final vers. Strasbourg.

- Goldstein, D. (2012). Analýza ichtyofauny České republiky se zaměrením na invazní druhy. Praha. Diplomová práce. Praha: Univerzita Karlova v Praze, Pedagogická fakulta, Katedra biologie a environmentálních studií.

- Hanel, L. (1989). Die Beziehung zwischen Körperlänge und - gewicht bei besonders grossen Fischen aus tschechoslowakischen Gewässern. Fischökologie, 1(1), 23-27.

- Hanel, L., \& Lusk, S. (2012) Biodiverzita ichtyofauny. In Ochrana prírody a krajiny $\checkmark$ České republice: Vybrané aktuální problémy a možnosti jejich řešení. 2. sv. (pp. 639-653). Olomouc: Univerzita Palackého v Olomouci.

- Holčík, J. (1990) Pravidlá postupu prii introdukcii exotických druhov rýb a vodných bezstavovcov do čSSR. InMetodiky Výzkumného ústavu rybářského a hydrobiologického (pp. 1-9). Vodñany: VúRH.

- Chráska, M. (2007). Metody pedagogického výzkumu: Základy kvantitativního výzkumu. Praha: Grada.

- Lusk, S., \& Lusková, V. (2005) Invazní druhy ryb v podmínkách české republiky. In Sbírka referátů z VIII. České ichtyologické konference (pp. 116-121). Brno: Ústav biologie obratlovců AV ČR.

- Lusk, S., Lusková, V., \& Halačka, K. (1998). Introdukované druhy ryb v ichthyofauně České republiky. Bulletin Lampetra, 3, 119-133.

- Lusk, S., Lusková, V., Halačka, K., \& Lojkásek, B. (2000). Změny v druhové skladbě ichtyofauny na území české republiky po roce 1990. Biodiverzita ichtyofauny České republiky, 3, 21-28.

- Lusk, S., Lusková, V., \& Hanel,L., (2008). Nepůvodní druhy v ichtyofauně České republiky - jejich vliv a význam.Biodiverzita ichtyofauny České republiky, 7, 96113.

- Lusk, S., Lusková, V., \& Hanel, L. (2011). Černý seznam nepůvodních invazivních druhů ryb české republiky.Biodiverzita ichtyofauny české republiky, 8, 79-97.

- Mlíkovský, J., \& Stýblo, P. (2006). Nepůvodní druhy fauny a flóry České republiky. Praha: ČSOP.

- Pelikán, J. (2011). Základy empirického výzkumu pedagogických jevů. Praha: Karolinum.

- Plesník, J. (2011). Někdo to rád horké. Invazní nepůvodní druhy. Ochrana prírody, 5, 37-29.

- Pokorná, L. (2011). Nepůvodní druhy ryb ve světle zákona o ochraně prírody. Ochrana prírody, 1, 12-13. 
Prof. RNDr. Lubomír Hanel, CSc.

Katedra biologie a ekologických studií, Pedagogická fakulta Univerzity Karlovy Praha, M. D. Rettigové 47/4, Praha 1, 116 39, e-mail: lubomirhanel@seznam.cz 